\title{
Wax Dosage Form
}

National Cancer Institute

\section{Source}

National Cancer Institute. Wax Dosage Form. NCI Thesaurus. Code C78750.

A semi-solid composed of lipids made up of hydrocarbons or esters of fatty acids; active and/or inert ing redient(s) are commonly suspended within the wax matrix layer. 